\title{
Strategi Komunikasi PT Indofarma Tbk dalam Membangun Kepercayaan Konsumen di Masa Pandemi
}

\author{
Aswini Paramesti' ${ }^{1}$, Yugih Setyanto ${ }^{2}$ \\ ${ }^{1}$ Fakultas Ilmu Komunikasi, Universitas Tarumanagara, Jakarta \\ Email: Aswini.915180165@stu.untar.ac.id \\ ${ }^{2}$ Fakultas Ilmu Komunikasi, Universitas Tarumanagara, Jakarta* \\ Email: yugihs@fikom.untar.ac.id
}

Masuk tanggal : 15-12-2021, revisi tanggal :06-01-2022, diterima untuk diterbitkan tanggal : 16-01-2022

\begin{abstract}
PT Indofarma Tbk (INAF) is a multinational company that produces various kinds of pharmaceutical products and is a manufacturerof medicines. The purpose of this study is to explain the communication strategy undertaken by PT Indofarma Tbk in building consumer trust during the pandemic and explain the efforts made by PT Indofarma Tbk in achieving positive consumer trust. This studey uses several supporting concepts, namely Public Relations, PR Strategy and consumer trust. The author's research were obtained through interviews, documentation, observation, and literature study. The result showed that the communication strategy implemented by PT Indofarma Tbk was carried out using a public relations strategy, namely publications, events, news, community involvement, information of image, lobbying and negotiation amd social responsibility. Efforts made by PT Indofarma Tbk in building positive consumer trust are carried out by providing service to communicate between companies and consumer. In addition, the benchmark can be seen with increased sales and branding during the pandemic, so the public can have a positive sense of trust in PT Indofarma Tbk.
\end{abstract}

Keywords: public relations, public relations strategy, consumer trust

\begin{abstract}
Abstrak
PT Indofarma Tbk (INAF) adalah perusahaan multinasional yang menghasilkan berbagai macam-macam produk farmasi dan menjadi produsen obat-obatan. Tujuan dari penelitian ini adalah untuk menjelaskan strategi komunikasi yang dilakukan oleh PT Indofarma Tbk dalam membangun kepercayaan konsumen di masa pandemi dan menjelaskan upaya yang dilakukan PT Indofarma Tbk dalam mencapai kepercayaan konsumen yang positif. Penelitian ini menggunakan beberapa konsep penunjang yaitu Public Relations, Strategi Public Relations, dan Kepercayaan Konsumen. Penulis menggunakan metode studi kasus. Subjek penelitian ini adalah public relations PT Indofarma Tbk. Sedangkan objek penelitian ini adalah strategi public relations yang digunakan oleh PT Indofarma Tbk dalam membangun kepercayaan konsumen. Data dari hasil penelitian penulis diperoleh melalui wawancara, dokumentasi, observasi, dan studi pustaka. Hasil penelitian menunjukkan strategi komunikasi yang dilakukan oleh PT Indofarma Tbk dilakukan menggunakan strategi public relations yaitu publications, events, news, community involvement, inform of image, lobbying and negotiation dan social responsibility. Upaya yang dilakukan PT Indofarma Tbk dalam membangun kepercayaan konsumen yang positif dilakukan dengan menyediakan layanan untuk berkomunikasi antara perusahaan dengan konsumen. Selain itu, tolak ukur dapat dilihat dengan penjualan dan branding yang meningkat di masa pandemi ini maka masyarakat dapat memiliki rasa kepercayaan yang positif terhadap PT Indofarma Tbk.
\end{abstract}

Kata Kunci: public relations, strategi public relations, kepercayaan konsumen 


\section{Pendahuluan}

Strategi pada dasarnya adalah sebuah perencanaan yang dilakukan untuk mencapai suatu tujuan. Dalam era globalisasi saat ini perkembangan media menjadi bagian dari strategi komunikasi yang secara aktif dapat mengalami perkembangan sehingga dapat meningkatkan daya tarik dan menjadikan sebuah informasi semakin mudah untuk di dapat dan tersampaikan pada setiap individu ataupun khalayak banyak. Menurut Effendi Gazali (dalam Tamara, 2018) terdapat 4 fungsi utama komunikasi yaitu untuk menginformasikan, mengarahkan, dan menyesuaikan.

Menurut Cutlip dan Broom (dalam Ruliana, 2015) mendefinisikan Public Relations merupakan fungsi manajemen yang menilai sikap khalayak, mengenali prosedur dan strategi organisasi dengan suatu kepentingan khalayak, dan merencanakan atau melakukan program tindakan dan komunikasi untuk menghasilkan interpretasi dan penerimaan dari publik.

Konsumen merupakan seseorang ataupun kelompok yang menggunakan suatu barang atau jasa. Konsumen menjadi salah satu faktor dari keberhasilan perusahaan. Dalam hal ini public relation harus memiliki strategi komunikasi yang baik untuk dapat membangun citra baik perusahaan sehingga terbentuk kepercayaan konsumen melalui image baik perusahaan yang dikenal orang banyak.

Di masa pandemi ini kasus Covid-19 kian meningkat yang menyebabkan kebutuhan obat dianggap potensial dan sudah dipakai dalam terapi Covid-19 menjadi tinggi. PT Indofarma Tbk merupakan perusahaan multinasional yang menghasilkan berbagai macam produk farmasi dan menjadi produsen obat-obatan. Tentu di masa pandemi ini media menjadi salah satu bagian strategi komunikasi yang dilakukan public relations untuk membangun kepercayaan konsumen. Hal tersebut dilakukan dengan mengedukasi masyarakat mengenai kesehatan agar dapat meningkatkan kualitas kesehatan masyarakat sehingga terbentuknya kepercayaan konsumen.

Menurut Rosady Ruslan (dalam Putri, 2019) mendefinisikan strategi public relations merupakan pilihan yang baik yang dapat dipilih untuk bisa mencapai suatu tujuan yang diinginkan public relations. Menurut Nova (dalam Putri, 2019) menjabarkan strategi public relations yaitu:

\section{Publications}

Publikasi merupakan upaya seorang PR dalam menyebarkan sebuah informasi kepada masyarakat atau khalayak banyak. Publikasi yang dilakukan dapat disebarkan di beberapa media online dan media sosial yang terkait dengan perusahaan.

2. Event

Merencanakan suatu kegiatan atau acara yang dilakukan oleh seorang PR dengan tujuan agar dapat mengenalkan suatu produk yang dimiliki oleh perusahaan. Event dibuat dalam bentuk seminar atau seperti acara rutin yang dilakukan perusahaan.

3. News

Sebuah data dan informasi yang disampaikan kepada masyarakat yang dapat dilakukan secara langsung dan juga melalui beberapa media sosial dan media online. Biasanya seperti press release dan newsletter bertujuan agar dapat diterima oleh khalayak.

4. Community Involvement

Sebuah hubungan yang dibangun untuk khalayak. Seperti media, stakeholder dan masyarakat sekitar perusahaan. Cara yang dilakukan dengan membuat 
suatu kegiatan ditujukan untuk dapat mendekatkan hubungan antara perusahaan terhadap khalayak nya.

5. Inform of Image

Upaya yang dilakukan public relations dalam memberikan suatu informasi dari perusahaan kepada masyarakat atau khalayak banyak yang diujukan untuk mendapatkan suatu citra positif dan dapat menarik perhatian dari masyarakat.

6. Lobbying and Negotiation

Kemampuan bernegosiasi yang dilakukan oleh PR menjadi strategi agar mampu mendapatkan kerja sama dengan menjalankan kegiatan yang dilakukan oleh perusahaan untuk keberhasilan perusahaan.

7. Social Responsibility

Wacana atau kegiatan tanggung jawab sosial yang dilakukan untuk memberikan rasa kepedulian suatu perusahaan dengan lingkungannya.

Dalam Sebuah hubungan yang dibangun public relations atas dasar kepercayaan, kejujuran dan kredibilitas. Public relations menjalankan suatu kegiatan yang dilakukan untuk menjalin komunikasi yang baik dengan publik sasarannya maupun organisasi atau perusahaan. Menurut Ledingham dan Brunig (dalam Agustine, 2013) kepercayaan merupakan salah satu karakteristik hasil dari sebuah relationship (hubungan) disamping komitmen, kepuasan, dan kontrol mutualitas.

Kepercayaan memiliki pengaruh yang cukup besar dalam perusahaan. Kepercayaan konsumen dapat terbentuk dengan berbagai upaya menjaga komunikasi yang baik dengan konsumen, dalam berbagai kegiatan yang dilakukan sebagai kredibilitas dan juga kepedulian sebuah perusahaan. Kepercayaan konsumen memiliki keterkaitan dengan citra perusahaan, apabila kepercayaan konsumen dapat terbentuk dan dinilai baik maka citra perusahaan akan baik. Heath dan Coombs (dalam susanto, 2019) mendefinisikan public relations merupakan sebuah fungsi manajemen yang terdiri dari perencanaan, publisitas, penelitian, pengumuman dan kerja sama. Hal tersebut ditujukan untuk dapat membantu perusahaan agar lebih memahami masingmasing orang yang bekerja sama. Maka dari itu hal tersebut dapat menghasilkan suatu hubungan yang bertimbalan dan menguntungkan untuk dapat mencapai suatu tujuan dari perusahaan.

\section{Metode Penelitian}

Penulis melakukan penelitian ini untuk dapat mengetahui strategi komunikasi yang digunakan oleh PT Indofarma Tbk dalam membangun kepercayaan konsumen di masa pandemi. Untuk dapat memenuhi hasil penelitian ini, penulis menggunakan sebuah metode penelitian yang sesuai terhadap masalah yang diamati oleh penulis.

Lalu pendekatan penelitian yang digunakan yaitu penelitian kualitatif. Pendekatan kualitatif adalah suatu pendekatan penelitian yang digunakan oleh penulis untuk meneliti suatu objek yang dianggap alamiah. Dalam penelitian ini, penulis memilih untuk menggunakan pendekatan kualitatif. Hal ini dikarenakan untuk mencari tahu strategi komunikasi apa yang dilakukan PT Indofarma Tbk dalam membangun kepercayaan konsumen di masa pandemi.

Sedangkan untuk metode penelitian yang digunakan adalah studi kasus. Menurut Lincoln dan Guba (dalam Rahardjo, 2017) studi kasus adalah suatu sarana yang baik dalam menentukan hubungan antara peneliti dengan subjek atau informan. Tujuan dari studi kasus adalah dapat mengembangkan suatu pengetahuan yang lebih 
mendalam terhadap suatu objek yang sedang diteliti. Menandakan bahwa studi ini bersifat sebagai suatu penelitian yang eksploratif.

Maka dari itu penulis ingin lebih mendalami dan menganalisis studi kasus lebih lanjut terhadap strategi PT Indofarma Tbk untuk dapat membangun kepercayaan konsumen. Studi kasus dalam penelitian ini digunakan untuk menjawab permasalahan penelitian yaitu mengetahui bagaimana strategi public relations yang digunakan oleh PT Indofarma Tbk dalam membangun kepercayaan konsumen.

Subjek dari penelitian ini adalah public relations dan marketing PT Indofarma Tbk sebagai key informan di dalam penelitian ini. Dalam hal ini public relations menjadi pihak yang berperan dalam mengatur strategi yang tepat untuk membangun kepercayaan konsumen. Kemudian, Objek dari penelitian ini adalah strategi Public Relations yang digunakan oleh PT Indofarma Tbk dalam membangun kepercayaan konsumen.

Metode pengumpulan data yang digunakan penulis adalah dengan dengan metode wawancara, dokumentasi, observasi dan studi pustaka. Wawancara dengan beberapa narasumber yang dianggap dapat mengetahui dan menguasai topik yang akan diteliti. Wawancara dengan Manager Corporate Secretary Wardjoko Sumedi, Public Relations Fera Amelia, Marketing Sriyono, dan Dosen Public Relations Dini Valdini. Metode wawancara ini dapat digunakan untuk menjawab permasalahan dalam penelitian dan dapat mengetahui strategi komunikasi yang dilakukan dalam membangun kepercayaan konsumen. Dokumentasi yang dilakukan oleh penulis berupa foto, press release, dan artikel dari media massa yang berkaitan dengan judul yang diamati penulis. Observasi dilakukan dengan mengamati PT Indofarma Tbk. Observasi yang dilakukan oleh penulis yaitu mengamati secara langsung untuk menemukan fakta di lapangan terhadap strategi yang dilakukan PT Indofarma Tbk dalam membangun kepercayaan konsumen. Studi pustaka dilakukan dengan mengumpulkan informasi dan data melalui jurnal, buku dan sumber penelitian. Lalu penulis menggunakan teknik triangulasi dalam menilai hasil data yang sudah didapatkan. Menurut Susan Stainback (dalam Bachri 2010:55) mendefinisikan bahwa triangulasi tujuannya bukan untuk menentukan kebenaran tentang fenomena sosial yang sama, melainkan tujuan triangulasi adalah untuk meningkatkan pemahaman seseorang tentang apa yang pernah diteliti. Dalam hal ini penulis akan menggunakan teknik triangulasi dengan membandingkan data hasil pengamatan dari informan dengan teori/konsep yang penulis dapatkan.

Penulis menggunakan teknik pengolahan dan analisis data dengan menggunakan reduksi data, penyajian data, dan penarikan kesimpulan. Penulis mengumpulkan seluruh informasi dengan wawancara, dokumentasi, observasi dan studi pustaka. Kemudian jika data telah terkumpul, maka penulis melakukan reduksi data adalah proses pemilihan suatu data yang didapatkan dari catatan-catatan tertulis di lapangan (Rijali, 2019:91). Penyajian data yang telah didapatkan oleh penulis dijadikan sebagai sebuah acuan agar dapat menarik kesimpulan mengenai strategi public relations yang dilakukan PT Indofarma Tbk dalam membangun kepercayaan konsumen. Kemudian kesimpulan perlu dikonfirmasi agar kesimpulan tersebut nantinya akan menghasilkan saran-saran yang berkaitan dengan penelitian. 
Aswini Paramesti, Yugih Setyanto: Strategi Komunikasi PT Indofarma Tbk dalam Membangun Kepercayaan Konsumen di Masa Pandemi

\section{Hasil Temuan dan Diskusi}

PT Indofarma Tbk merupakan perusahaan multinasional yang menghasilkan berbagai macam obat-obatan dan menjadi produsen obat. Dalam hal ini public relations sebagai pendukung PT Indofarma Tbk dalam menjalankan fungsinya, public relations memiliki tujuan untuk dapat membangun citra organisasi yang baik untuk masyarakat dan khalayak luas. Philip Kitchen (dalam Raturahmi, 2021) mendefinisikan public relations pada dasarnya adalah sebuah fungsi komunikasi, tetapi dengan penekanan pada sifat dua arah dari proses komunikasi, berkaitan dengan cara membangun saling pengertian antara organisasi dan kelompok orang tertentu. Kegiatan public relations semenjak masa pandemi ini meningkat baik secara internal dan juga eksternal. Sesuai dengan tujuan dan visi misi perusahaan di dalam Corporate Communication melakukan kegiatan untuk dapat membangun branding image PT Indofarma Tbk, menjaga image perusahaan, menyampaikan pesannya dari perusahaan kepada masyarakat atau konsumen, menciptakan reputasi yang baik untuk perusahaan. Hal tersebut dilakukan untuk dapat mendekatkan antara perusahaan kepada konsumennya. Strategi komunikasi yang dilakukan oleh PT Indofama Tbk dalam membangun kepercayaan konsumen di masa pandemi menggunakan strategi public relations dan proses yang dilakukan.

Menurut Cutlip (dalam Putri, 2019) menjabarkan proses kerja strategi PR yaitu:

1. Fact Finding

Tahap ini public relations PT Indofarma Tbk melakukan suatu observasi yang menyangkut isu-isu atau permasalahan yang terjadi pada perusahaan seperti adanya komentar-komentar negatif, dan berita negatif mengenai PT Indofarma Tbk di beberapa media sosial yaitu instagram dan media online lainnya seperti isu yang terkait dengan produk oseltamivir prosphate. Pada hal ini public relations mengumpulkan sejumlah data-data yang terkait dengan isu tersebut dan mencari tahu permasalahan apa yang berhubungan dengan perusahaan.

\section{Planning}

Informasi yang didapatkan maka seorang public relations dapat membuat sebuah perencanaan atau strategi untuk mencapai suatu tujuan tertentu. Public relations PT Indofarma Tbk membuat perencanaan untuk menentukan waktu yang tepat dan memakai beberapa media sosial seperti instagram, twitter dan facebook untuk mempublikasi hal tersebut berupa press release atau konfrensi pers. Hal tersebut dilakukan langkah demi langkah agar perencanaan yang telah ditetapkan dapat dilakukan dengan matang.

3. Communication

Pada tahap ini yaitu pelaksanaan program tindakan maka public relations PT Indofarma Tbk melakukan berbagai diskusi untuk mendengar keinginan dari berbagai pihak yang terkait. Selain itu pesan yang disampaikan juga dapat menggiring opini, sikap dan juga publik bahwa mengenai isu atau permasalahan negatif yang berhubungan dengan PT Indofarma Tbk itu tidak benar adanya. Pesan atau informasi yang disampaikan juga menggunakan komunikasi yang harus dapat dimengerti oleh masyarakat dan tata cara dalam menjawab sesuai dengan aturan yang berlaku pada perusahaan. Selain itu media yang digunakan harus tepat seperti instagram menjadi wadah untuk mempublikasi mengenai informasi yang menyangkut dengan perusahaan seperti adanya press release, berita dan artikel terkait isu yang ada. 


\section{Evaluation}

Perencanaan yang sudah dibuat harus dapat dievaluasi untuk dapat mengukur suatu keberhasilan yang akan dicapai. Dalam hal ini public relations PT Indofarma Tbk akan melakukan penilaian persiapan dan mengumpulkan pendapat dengan beberapa rekan kerja yang lain. Pada tahap ini dipastikan bahwa perencanaan dan komunikasi yang sudah direncanakan tersebut dapat membangun kepercayaan konsumen di PT Indofarma Tbk dengan strategi yang dilakukan.

Menurut Hardiman (dalam Agustine, 2013) mendefinisikan customer relations merupakan suatu usaha dalam menjalin hubungan baik antara perusahaan atau organisasi dengan konsumennya. Hal tersebut dilakukan untuk menciptakan kepuasan dan kepercayaan melalui hubungan komunikasi yang dilakukan baik secara langsung ataupun tidak langsung. Dalam hal ini strategi yang dilakukan oleh public relations dapat membangun kepercayaan konsumen yang positif didalam perusahaan disebut dengan value pembelian yang terlihat saat PT Indofarma Tbk memproduksi produkproduk yang berkaitan dengan Covid-19. Kepercayaan konsumen penting untuk perusahaan sebagai sumber cash flow perusahaan. produk-produk yang dihasilkan PT Indofarma Tbk digunakan oleh konsumen perusahaan maka dari itu konsumenya harus dapat dijaga dengan baik.

Dalam hal ini website resmi PT Indofarma Tbk yang menyediakan layanan untuk konsumennya berkomunikasi dengan pihak perusahaan terlihat yaitu dengan adanya pertanyaan yang diajukan mengenai produk perusahaan. Public relations berusaha untuk tetap memberikan yang terbaik dengan memberikan jawaban mengenai informasi lebih detail tentang produk yang membuat konsumen merasa lebih percaya dengan informasi yang didapatkan secara resmi.

Hal lainnya di masa pandemi ini terlihat dari penjualan produk yang diproduksi perusahaan berkaitan dengan Covid-19. Dengan penjualan yang meningkat di masa pandemi ini maka konsumen dapat memiliki rasa kepercayaan yang postif terhadap PT Indofarma Tbk melalui strategi yang dilakukan oleh public relations perusahaan. Dalam menangani permasalahan yang terkait dengan konsumen seorang public relations dapat menghandle hal tersebut dengan cepat agar hal tersebut tidak mengganggu untuk yang lainnya karena konsumen merupakan hal yang penting dalam perusahaan untuk kemajuan perusahaan.

\section{Simpulan}

Dari pengamatan yang sudah dijalankan oleh penulis, kesimpulan menunjukkan bahwa strategi public relations yang dilakukan PT Indofarma Tbk dalam membangun kepercayaan konsumen adalah melakukan publications yang ditujukan untuk memberikan informasi dan pemahaman lebih jelas mengenai perusahaan kepada khalayaknya melalui media online dan media sosial, event untuk memperkenalkan produk perusahaan maupun layanan perusahaan, news dengan pembuatan press release yang bertujuan untuk memberikan informasi perusahaan agar diterima oleh masyarakat, community involvement yang bertujuan untuk dapat menjaga hubungan baik antara PT Indofarma Tbk dengan komunitasnya, inform of image yang dilakukan untuk menghasilkan citra yang baik dari masyarakat, lobbying and negotiation untuk memperoleh kerja sama dengan organisasi dan social 
responsibility dengan beberapa program atau kegiatan bantuan obat-obatan untuk menunjukkan kepeduliannya terhadap suatu perusahaan kepada masyarakat.

Upaya yang dilakukan PT Indofarma Tbk untuk mencapai kepercayaan konsumen yang positif dengan menyediakan layanan untuk konsumennya berkomunikasi dengan pihak perusahaan yang dinamakan layanan Pharmacovigilance. Dalam menangani permasalahan yang terkait dengan konsumen mengenai produk perusahaan maka public relations akan melakukan konfirmasi dan menjawab mengenai informasi lebih detail tentang produk yang membuat konsumen merasa lebih percaya dengan informasi yang didapatkan secara resmi. Selain itu, tolak ukur dapat dilihat dengan penjualan dan branding yang meningkat di masa pandemi ini maka konsumen dapat memiliki rasa kepercayaan yang positif terhadap PT Indofarma Tbk melalui strategi yang dilakukan oleh public relations perusahaan.

\section{Ucapan Terima Kasih}

Penulis mengucapkan terima kasih kepada Tuhan Yang Maha Esa, dengan narasumber yang terkait dengan penelitian ini, orang tua, keluarga, dan teman serta kepada seluruh pihak yang sudah membantu dan memberikan semangat, ide dan motivasi kepada penulis dalam menyelesaikan penelitian dan jurnal ini.

\section{Daftar Pustaka}

Bachri, B. S. (2010). Meyakinkan Validitas Data Melalui Triangulasi Pada Penelitian Kualitatif. Universitas Negeri Surabaya, 46-62.

Loryna, A. (2013). Pengaruh Kualitas Program Customer Relations Terhadap Tingkat Kepercayaan Pelanggan PT. Pos Indonesia. 1-55.

Rahardjo, M. (2017). Studi kasus dalam penelitian kualitatif: konsep dan prosedurnya. Universitas Islam Negeri Malang.

Raturahmi, L., S.Y, R. U. D., \& Meisani, S. (2021). Strategi Komunikasi PT.Pos Indonesia Dalam Meningkatkan Reputasi Perusahaan. Journal Digital Media \& Relationship, 3(1), 30-42. http://ejurnal.ars.ac.id/index.php/jdigital/article/view/415

Rijali, A. (2019). Analisis Data Kualitatif. Alhadharah: Jurnal Ilmu Dakwah, 17(33), 81-95. https://doi.org/10.18592/ALHADHARAH.V17I33.2374

Ruliana, P., \& Dwiantari, R. (2015). Strategi Public Relations Hotel dalam Membentuk Citra Objek Wisata. Jurnal ASPIKOM, 2(4), 255-271. https://doi.org/10.24329/ASPIKOM.V2I4.76

Susanto, A. S., \& Setyanto, Y. (2020). Strategi Public Relations SmartSpin PR dalam Membangun Brand Image Klien (Studi Pada Re:ON comics). Prologia, 3(2), 320 326. https://journal.untar.ac.id/index.php/prologia/article/view/6349

Tamara, J., \& Setyanto, Y. (2019). Strategi Public Relations dalam Membangun Brand Image Jamu (Studi pada Suwe Ora Jamu Kedai Jamu \& Kopi). Prologia, 2(2), 377-384. https://journal.untar.ac.id/index.php/prologia/article/view/3715 